\title{
標準新有効温度（SET*）における放射，湿度，気流，着衣 の影響の温度換算
}

\author{
INDIVIDUAL TEMPERATURE EXPRESSION FOR EACH INFLUENCE \\ OF THERMAL RADIATION, HUMIDITY, AIR VELOCITY \\ AND CLOTHING INSULATION REGARDING SET*
}

\author{
深井一夫* \\ Kazuo FUKAI
}

\begin{abstract}
Standard New Effective Temperature (SET*, Gagge et al.,1986) is a single temperature index of human response to a thermal environment. Therefore SET* can not individually describe each influence from thermal factors, that is, radiation, humidity, air velocity, clothing insulation and activity. In this paper, a method to individually express the thermal influences of radiation, humidity, air velocity and clothing insulation with the exception of activity in temperature scale are proposed. SET* was indicated as the value adding temperatures capable of expressing the influences of the four thermal factors mentioned above to the air temperature of the actual environment as a basal temperature.
\end{abstract}

Keywords : Standard New Effective Temperature, thermal factors, thermal index, loci for constant thermal sensation

S E T*, 温熱要素，温熱指標，等温感線

1.はじめに

温熱指標の一つである新有効温度 (New Effective Temperature : ET* ) は，実在環境と温熱的に等価な相対 湿度を $50 \%$ に標準化した平均放射温度と気温が等しい 環境の気温として，その基本的概念が1971年にGagge, Stolwijk, Nishi ${ }^{1)} に よ り$ 発表された。その後湿度に加えて 気流と着衣についても標準化した標準新有効温度 (Standard New Effective Temperature :SET*)がGagge, Nishi, Gonzalez $z^{2)}$ により示され，さらに1986年には Gagge, Fobelets, Berglund ${ }^{3)} に よ り \mathrm{ET}^{*}$ からSET*への標準化の方 法などに修正がなされ，代謝量の異なる場合にも相互に SET*の值を比較できる様に改良したSET*か提案されだ。

SET*は複数の温熱要素を総合して，単一の温度で表 す温熱指標（単一温度指標）であり，温熱感覚との対応 を明らかにしておけば，環境側の気温，放射，湿度、気 流の温熱 4 要素と人体側の着衣量, 代謝量のすべての温 熱要素を考慮して温冷感の予測や温熱環境の評価が単一 の数值により可能となる。そこで，筆者ら ${ }^{4) ~(8)}$ は日本人
を被験者とした実験的検討により，代謝量や着衣量の異 なる場合も含めてSET*と日本人の温熱感覚との対応を 明かにしてきた。しかし一方ではSET*が単一温度指標 であるがために，個々の温熱要素の影響を個別に把握す ることができない。温熱要素の影響の分離表現を考えた 温熱指標としては, 堀越ら”の放射, 湿度, 気流の影響 を分離して表し, 温度変換して気温に加えあわせた数值 で示す修正湿り作用温度があり，人と周囲環境亡の間の 熱平衡式に基ついて理論的に導出された指標で実験的な

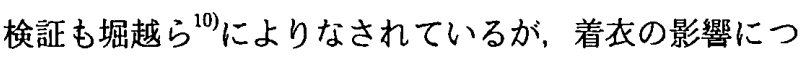
いては表現されていない。本論文では, 着衣の効果も考 虑され既に広く用いられているSET*において，与えら れた温熱条件からSET*を導出する過程を検討し, 代謝 を除く放射, 湿度, 気流, 着衣の各温熱要素の影響を温 度換算して，基準となる気温にそれぞれの温度換算值を 加算することによりSET*を表現する方法について報告 する。代謝に関しては前述のように1986年にGaggeら ${ }^{3) か ゙ ~}$ 発表したSET*では，異なる代謝量でのSET*の值を相互

\footnotetext{
$*$ 横浜国立大学工学部建築学教室 助手 $\cdot$ 工修
} 
に比較できるように改良され，筆者らのが行った軽歩行 程度の比較的低い代謝量の範囲での被験者実験の結果か らも，代謝量の異なる場合にもSET*之温冷感の関係は ほぼ等しいことを確認しており，SET*における代謝量 に関する考愿に実用上の問題はないと考えられるが，代 謝量の相違は人体熱収支への影響が大きく生理的状態值 も大きく変化し, 異なる代謝量での温熱的等価性等の理 論的な根拠に疑問を感じるため，代謝量の影響の温度換 算については本論文では除外する。

なお，本論文で用いる人体の生理的状態値を算出する ための体温調節数値モテル（2 節モテル）およびET*， SET*の計算は1986年のGaggeらの論文 ${ }^{3)} に$ にされるプロ グラムを基にしている。

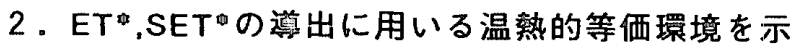 す“ Gaggeらの等温感線”}

Gagge らは，実在環境と温熱的に等価であるための条 件を，人体の生理的状態値であるぬれ面積率・皮局温・ 皮府表面での放熱量の三者が等しいことで規定して, 皮 府表面での熱収支式よりこの条件を満たす環境を示す湿 り空気線図上の直線を導き，ET*およびSET*の導出に用 いた。すなわち皮虔表面での熱収支は，代謝量のうちの 呼吸にともなう放熱以外の伝導と血流により皮辡表面へ 伝わる熱量と皮有表面での乾性および湿性放熱量が等し いとした下式で表される ${ }^{11)}$ 。

$\mathrm{Msk}=\mathrm{Hsk}=\mathrm{h} \cdot \mathrm{Fcl} \cdot(\mathrm{Tsk}-\mathrm{To})$

$$
+\mathrm{W} \cdot \mathrm{he} \cdot \mathrm{Fpcl} \cdot\left(\mathrm{Psk}^{*}-\mathrm{Pa}\right) \quad\left[\mathrm{W} / \mathrm{m}^{2}\right]
$$

ただし，

-Msk :体内から皮雇表面へ伝導と血流により伝わ 万熱量（代謝量－呼吸放熱量） [ $\left[\mathrm{W} / \mathrm{m}^{2}\right]$

-Hsk : 波简表面から周囲の環境への全放熱量

$\left[\mathrm{W} / \mathrm{m}^{2}\right]$

- Tsk :皮澼温

- w : ぬれ面積率

[N.D.]

- Psk* : 波虑温(Tsk)での飽和水蒸気压

- To : 作用温度

$\cdot \mathrm{Pa}$ :環境の水蒸気压

- h : :総合熱伝達率 (=hc+hr)

- $\mathrm{Fcl}$ :着衣の伝熱効率係数

[N.D.]

- he :蒸発に伴う物質熱伝達率

$\left[\mathrm{W} / \mathrm{m}^{2} / \mathrm{kPa}\right]$

- Fpcl :着衣の透湿効率係数

[N.D.]

また,

$\mathrm{To}=(\mathrm{hc} \cdot \mathrm{Ta}+\mathrm{hr} \cdot \mathrm{Tr}) / \mathrm{h}$

- $\mathrm{Ta}$ :気温

- $\operatorname{Tr}$ : 放射温度

- hc : 対流熱伝達率 h $\cdot \mathrm{hr} \quad \mathrm{Fcl}=-\frac{1.0}{\text { 放射熱伝達率 }} \begin{array}{r}{\left[\mathrm{W} / \mathrm{m}^{2} / \mathrm{K}\right]} \\ \text { Icl }+1.0 /(\mathrm{h} \cdot \mathrm{fcl})\end{array} \quad \ldots \ldots \ldots \ldots \ldots \ldots \circ(3)$

- Icl :着衣の熱抵抗 $(=0.155 \cdot I c l o) \quad\left[\mathrm{m}^{2} \mathrm{~K} / \mathrm{W}\right]$ $0.155:$ 単位変換の定数 $\left(\mathrm{clo} \rightarrow \mathrm{m}^{2} \mathrm{~K} / \mathrm{W}\right)$

・Iclo :ク口值で表した着衣の熱抵抗 [clo]

- fcl : 体表面皘に対する着衣表面積の割合 [N.D.] $\mathrm{fcl}=1.0+\mathrm{Kclo} \cdot \mathrm{Iclo}$

-Kclo :クロ值からfclを推定する定数］ [N.D.] he $=\mathbf{L R} \bullet \mathrm{hc}$

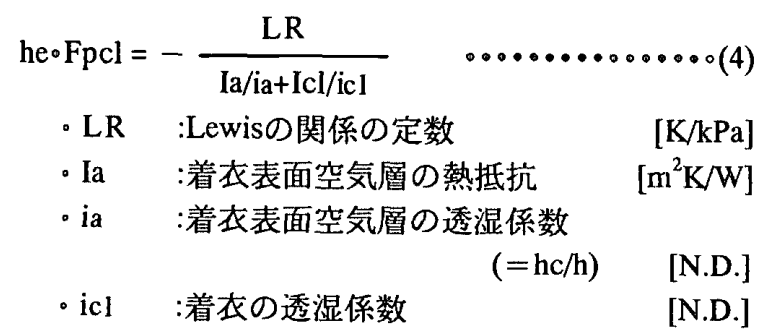

本論文で用いる1986年版の 2 節モデル゙)では，上記の 各係数のうちのいくつかは，以下の様な式あるいは定 数が使用されている。

・対流熱伝達率 hcは気流速度または代謝量から下 式により算定され，両者のうちの大きな值が用い られる。ただし最小值は $3 \mathrm{~W} / \mathrm{m}^{2} / \mathrm{K}(0.137 \mathrm{~m} / \mathrm{s} の$. 気流に相当）である。 $\mathrm{hc}=8.6 \cdot \mathrm{V}^{0.53}$ $\mathrm{hc}=5.66 \cdot(\mathrm{M} / 58.15-0.85)^{0.39}$ $\begin{array}{rrr}\text { ただし, } V & \text { :気流速度 } & {[\mathrm{m} / \mathrm{s}]} \\ M & : \text { :代謝量 } & {\left[\mathrm{W} / \mathrm{m}^{2}\right]}\end{array}$

- Kclo $=0.25$

- $\mathrm{LR}=15.1512 \cdot(\mathrm{Tsk}+273.15) / 273.15$

- $\mathrm{a} a=\mathbf{0 . 4 5}$

- icl $=0.45$ (通常着衣)

(1)式を作用温度(To)と水蒸気压(Pa)の関係にまとめる と,

$$
\begin{aligned}
& \mathrm{Pa}=-(\phi / \mathrm{w}) \cdot \mathrm{To}+\left[\mathrm{Psk}^{*}-\frac{\mathrm{Hsk}-\mathrm{h} \cdot \mathrm{Fcl} \cdot \mathrm{Tsk}}{\mathrm{w} \cdot \mathrm{he} \cdot \mathrm{Fpcl}}\right] \\
& \text { ただし， } \phi=(\mathrm{h} ・ \mathrm{Fcl}) /(\mathrm{he} \cdot \mathrm{Fpcl})
\end{aligned}
$$

ここで代謝量および気流速度・着衣量を固定すれば各 伝熱係数 ( $\mathrm{h}, \mathrm{Fcl}, \mathrm{he}, \mathrm{Fpcl})$ は定数となる。さらに皮虔温 (Tsk), 好面皘率(w), 皮膚面放熱量(Hsk) が一定であると すれば，(5)式右辺第 1 項のうちの $(\phi / w)$ と第 2 項は定 数亡みなせ，(5) 式は環境の水蒸気圧 $(\mathrm{Pa})$ に関する作用温 度(To)の一次式となる。つまり Tsk,w,Hsk がともに等し く，(1) 式で表される皮周表面における熱収支式が成立 する環境のToとPaは線形関係にあり，その軌跡はToを 横軸, Paを縦軸としたToとPaの直交する空気線図上で 傾きー $(\psi / \mathrm{w})$ の直線となる。Gaggeらはこの直線を温熱 的に等価な環境を示す等温感線であるとし，本論文では “ Gaggeらの等温感線”と表記する。この直線は与えら 
れた環境の温湿度条件を示す空気線図上の点を通り，相 対湿度 $50 \%$ 線との交点の温度が，相対湿度を50\%に標準 化した等価環境の温度つまりET*である。したがって， ET*は次式を満足するような温度として，反復計算によ り求められる。

$$
\begin{aligned}
\mathrm{Hsk}=\mathrm{h} \cdot \mathrm{Fcl} \cdot\left(\mathrm{Tsk}-\mathrm{ET}^{*}\right) & \\
& +\mathrm{w} \cdot \mathrm{he} \cdot \mathrm{Fpcl} \cdot\left(\mathrm{Psk}^{*}-0.5 \cdot \mathrm{P}_{\mathrm{ET}}{ }^{*}\right)
\end{aligned}
$$$$
\text { (............(6) }
$$

ただし，

- $\mathrm{P}_{\mathrm{ET}}{ }^{*}$ : 温度 $\left(\mathrm{ET}^{*}\right)$ での飽和水蒸気圧

[kPa]

SET*は，気流速度および着衣量を標準值として(5)式 の中の各伝熱係数を再度算出し，新たなGaggeらの等温 感線を求めて，ET*同様に相対湿度 $50 \%$ 線との交点の 温度を(6)式にならい求めたものである。

\section{3. 各温熱要素の影噼の温度換算}

本論文で扱う影響を分離して温度換算する温熱要素は， 代謝量を除いた放射・湿度・気流・着衣量の 4 つである。 このうち放射については，人体側の生理的状態とは直接 の関連を持たない人体と環境との間の対流および放射熱

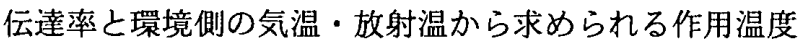
に基づいて評価することとし，本論文で扱う他の 3 つの 要素に先立ち独立にその効果を温度換算して表示する。 一方, 湿度・気流・着衣量の 3 つの温熱要素の影響の温

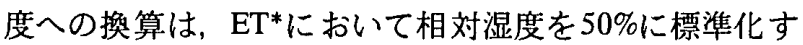
る方法と同様の考え方を用いる。つまり，与えられた温 熱条件から 2 節モテルを用いて求めた生理的状態值であ る皮虔温・ぬれ面積率・皮虚表面での放熱量の三者が等 しいことを温熱的に等価であることの条件として、ひと つあるいは複数の温熱要素を標準化したときの等価環境 の気温を上記のGaggeらの等温感線を用いて求め，標準 化する前の状態の気温との差をもって，その標準化した 温熱要素の標準值からの偏差の影響と見なす。ただし， 湿度・気流・着衣量は，人体側の生理的状態值と相互に 影響を及ぼし合うため，それぞれ互いに完全には独立で ない。したがって，3つの温熱要素の影響を温度換算し た值は，それぞれの要素を標準化する順番に多少の影響 を受けることになるが、この点に関する詳しい考察は後 に述べこととし，まず，それぞれの温熱要素の影響の 温度換算の方法について述べる。

\section{3-1 放射の影墼}

放射による影響は，先にも述べたように，作用温度 (To)により評価する。Toは実環境と人体熱収支の上で等 価な平均放射温度と気温の等しい環境の気温によって表 され，気温と放射温をそれぞれ対流熱伝達率と放射熱伝
達率で重み付けした平均温度で，前出の(2)式である。 放射の影響を温度換算したものを実環境の気温と作用 温度の差として表現することとしたので，この放射の影 響を $\Delta \operatorname{Trad}$ 表記すると，

$\Delta \mathrm{Trad}=\mathrm{To}-\mathrm{Ta}=\mathrm{hr} \cdot(\mathrm{Tr}-\mathrm{Ta}) / \mathrm{h} \quad \cdots \cdots \cdots \cdot(7)$ これは既にGaggeら ${ }^{12)} に よ り$ 提案されている放射の影 響を分離して表す有効放射場 (ERF=hr ・ $(\mathrm{Tr}-\mathrm{Ta}))$ の考え 方そのもので, ERFを総合熱伝達率 hで除して温度の単 位に変換したものが $\Delta \operatorname{Trad}$ である。

$\triangle \mathrm{Trad}=\mathrm{ERF} / \mathrm{h}$

Toを気温と放射の影響の温度換算值の和で表せば,

$\mathrm{To}=\mathrm{Ta}+\Delta \mathrm{Trad}$

作用温度では湿度に関しては何ら規定できないが，実 環境との等価性を維持するためには，湿度に関しても規 定しておくことが必要で，皮虚表面での湿性放熱を等し くするような湿度を考える。皮虔表面での湿性放熱量は， ぬ好面積率が等しければ皮覤温における飽和水蒸気圧と 環境の水蒸気圧との差に比例することから，等しい湿性 放熱を得るには水蒸気压を実環境と等しく保つ必要があ る。したがって，作用温度を用いるときの相対湿度は， 水蒸気圧が実環境亡等しく温度が作用温度の值であると きの相対湿度で表す。

\section{$3-2$ 湿度の影響}

湿度の標準値をRH50\%とし，温熱的等価性を保ちつ つ湿度のみをRH50\%に標準化するために必要とされる 気温の変化量を湿度の影響の温度換算值とする。すなわ ち、上記の放射の影響を考慮した作用温度と実環境の水 蒸気圧により決まる空気線図上の点を通過する Gaggeら の等温感線を，与えられた温熱条件のもとで 2 節モデ により求めた生理的状態值等から決定する。そして，こ の等温感線とRH50\%線との交点の温度つまり $\mathrm{ET}^{*}$ の值を 求め，もとの作用温度との差を湿度の影響の温度換算值 とする。これを $\Delta$ Thum と表記すれば,

$\Delta$ Thum $=\mathrm{ET}^{*}-\mathrm{To}$

ET*気温とそれぞれの温熱要素の温度換算値の和と して表せば,

$\mathrm{ET}^{*}=\mathrm{Ta}+\Delta \mathrm{Trad}+\Delta \mathrm{Thum}$

\section{3-3 気流の影響}

ET*は上記のごとく放射および湿度を標準化したもの であるが，次に気流を標準化し，気流の影響の温度換算 値を求める。

気流は直接には対流熱伝達率 hcに影響を及ぼし，hc は第 2 節に示したとおり気流速度または代謝量により決 定される。気流の標準值としては静穞気流，すなわち hc を $3.0 \mathrm{~W} / \mathrm{m}^{2} / \mathrm{K}$ とする。ただし，与えられた代謝量より求 まるhcが $3.0 \mathrm{~W} / \mathrm{m}^{2} / \mathrm{K}$ 越える場合にはその值を採用し， 
例えば椅座作業時の代謝量として用いられる1.1metでは

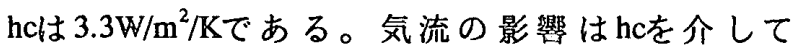
$\mathrm{h}, \mathrm{he}, \mathrm{Fcl}, \mathrm{Fpcl}$ 各伝熱係数を変化させ, 新たに(5)式によ り示される Gaggeらの等温感線を求め，ET*同様にこ の等温感線上のRH50\%となる環境の気温を求める。こ の温度は, 放射・湿度を標準化したET*をさらに気流に ついて標準化した温熱的等価環境の温度を意味し， ET*vel と表記する。したがって，気流の影響を温度換 算した值を放射・湿度の場合と同様に $\Delta$ Tvel と表記す れば,

$$
\Delta \mathrm{Tvel}=\mathrm{ET}^{*} \mathrm{vel}-\mathrm{ET}^{*}
$$

また，Taを基準にすれば，ET*等と同様に，

$\mathrm{ET}^{*} \mathrm{vel}=\mathrm{Ta}+\Delta \mathrm{Trad}+\Delta \mathrm{Thum}+\Delta \mathrm{Tvel}$

と表すことができる。

\section{3-4 算衣の影饗}

着衣の標準值は，1986年版のSET*プログラムでは， 代謝量の異なる条件間でのSET*の相互比較を可能とす るために(14)式で示される代謝量 $\mathrm{M}$ の関数としての標準 着衣量Icls（clo単位）を用いている。すなわち,

Icls $=1.33 /[(\mathrm{M}-\mathrm{W}) / 58.15+0.74)]-0.095 \quad \circ \circ(14)$

ただし、W:外部になした仕事量 $\left[\mathrm{W} / \mathrm{m}^{2}\right]$
この標準着衣量を算出する(14)式の導出に関する理論的 な根拠についてはGaggeら ${ }^{3)}$ の論文の中にも述へらられて

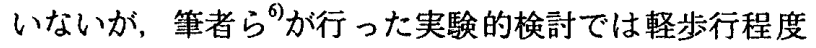
までの活動度においては，(14)式の標準着衣量を用いる ことにより，代謝量の異なる場合にもSET*と温冷感の 関係がほぼ同様に保持されていることが確認できた。ま た，本論文ではSET*そのものに対する新たな提案を行 うことが目的ではなく，既存のSET*における各温熱要 素の影響の温度換算を可能にすることを目的としている ため，着衣量の標準値としては，代謝量に応じて(14)式 により求まる值をそのまま用いることとする。(5)式の Gaggeらの等温感線においては，着衣量を標準化するこ とにより FclおよびFpcl が変化して、新たな等温感線が 決まる。この等温感線とRH50\%線との交点の温度が SET*であり，ET*velの着衣量を標準化した等価環境の 温度とも見られる。着衣量の影響の温度換算値を $\Delta$ Tclo と表記すれば,

$$
\Delta \text { Tclo }=\text { SET }^{*}-\text { ET }^{*} \text { vel }
$$

また，Taを基準にすれば，

$$
\mathrm{SET}^{*}=\mathrm{Ta}+\Delta \mathrm{Trad}+\Delta \mathrm{Thum}+\Delta \mathrm{Tvel}+\Delta \mathrm{Tclo}
$$

と表すことができる。したがって，SET*の値を気温を

[kPa]

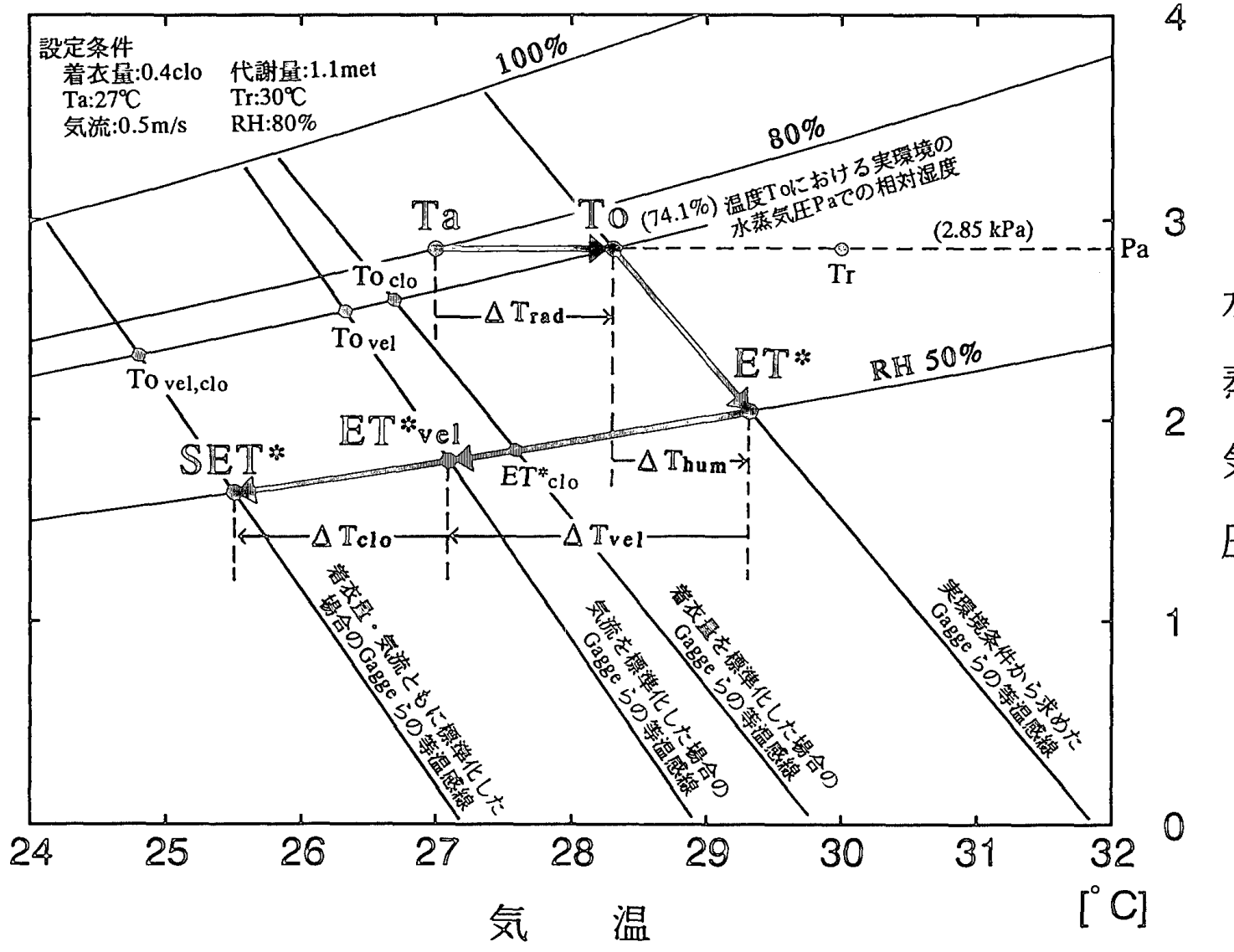

水

蒸

気

圧

図 - 1 温熱要素を標準化した等価環境の温度と温熱要素の影響の温度換算値の関係 
基準として放射・湿度・気流・着衣の影響をそれぞれ温 度換算したものに分離し，その総和として表現できたこ とになる。

図ー1には気温から1つまたは複数の温熱要素を標準 化した等価環境の温度を経てSET*に至る過程を示す。 設定条件は次節に示す例之同一である。

\section{4. 標準化の順番の相違による温度換算値の差}

与えられた温熱条件から各温熱要素の影響を温度換算 し、気温を基準として各要素の影響の温度換算值の総和 としてSET*を表せることを前節に示したが，先にも述 べたように，湿度・気流・着衣量の影響の温度換算では 標準化の順番の相違により温度換算值に差が生じる。例 えば，湿度の影響を考える場合，着衣量が実際の值での 湿度の影響と，着衣量を標準値とした条件での湿度の影

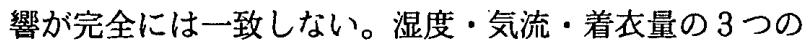
温熱要素の影響の温度換算値は，換算の順番を考慮する と各要素について4つづつ考えられるので，これらにつ いて検討する。

一例として代謝量は椅座作業時程度の $1.1 \mathrm{met}$ 、気温 $27^{\circ} \mathrm{C}$,放射温 $30^{\circ} \mathrm{C}$, 相対湿度 $80 \%$,気流 $0.5 \mathrm{~m} / \mathrm{s}$, 着衣量 $0.4 \mathrm{clo}$ の条件を想定する。筆者ら ${ }^{4), 5}$ の央験結果によると中立 的温冷感 (やや涼しい やや暖かい) の得られるSET*

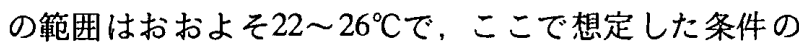
SET*が $25.51^{\circ} \mathrm{C}$ とることから，この温熱環境は放射温 がかなり高くまた高湿であるが，緩やかな気流 $(0.5 \mathrm{~m} / \mathrm{s})$

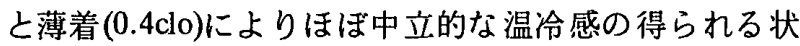
態と判断できよう。前節に示した方法にしたがって放射・ 湿度・気流・着衣量の影響を温度換算するが，湿度・気 流・着衣量の標準化の順番を換えることにより，以下に 示す新たな 4 つの指標が定義できる。すなわち，

・ To vel :気流を標準化した作用温度

・Toclo :着衣量を標準化した作用温度

・To vel,clo :気流および着衣量を標準化した作用温 度到1

・ET*clo :着衣量を標準化したET*

また先に述べたように，作用温度を用いるときの相対 湿度は与条件の相対湿度とは異なり，与条件と水蒸気王 が等しいまま温度を作用温度としたときの相対湿度(こ の条件では74.1\%) であり，湿度を標準化しない場合の 等価環境の湿度としてはこの值を用いる。

図一2には，実環境を出発点として各温熱要素の影響 の温度換算值および各指標の值を，それぞれの標準化の 順番を追って示している。

この例では，放射の影響の温度換算値は(7)式により $+1.31^{\circ} \mathrm{C}$ となる。つぎに湿度の影響すなわち相対湿度が 標準值の50\%に比較して高湿であることの効果を温度に
換算すると，標準化の順番の相違により $+0.71 \sim+1.01^{\circ} \mathrm{C}$ の幅を持つ。標準化前の温度が高い場合には，標準化前 後での水蒸気圧の差が大きく，また標準化に用いる Gaggeらの等温感線の空気線図上での負の傾きが小さく なるために温度換算値が大きくなる。また，気流が大き い場合や着衣量が小さい場合にも温度換算值が大きくな る傾向があるが，これは気流が大きく着衣量が小さいほ どGaggeらの等温感線の負の傾きが小さくなることに起 因していると考えられる。つぎに標準とした静穏気流に 比へて大きな $0.5 \mathrm{~m} / \mathrm{s}$ の気流の効果の温度換算値は -1.89 $\sim-2.23^{\circ} \mathrm{C}$ で，湿度が低く皮虚表面での湿性熱放散の生 じやすい場合や，着衣量が少なく乾性熱放散の生じやす い場合に，その絶対值が大きくなる。着衣量では, 1.1metでの標準着衣量 0.63 clo よりも少ない0.4clo とし

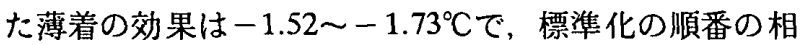
違による差は小さい。平均値としてみると湿度の効果は $+0.85^{\circ} \mathrm{C}$ (標準偏差 $0.14^{\circ} \mathrm{C}$ ), 気流の効果は $-2.05^{\circ} \mathrm{C}$ (標 集偏差 $0.14^{\circ} \mathrm{C}$ )，薄着の効果は $-1.61^{\circ} \mathrm{C}$ （標準偏差 0.09 ${ }^{\circ} \mathrm{C}$ ) で，与条件の気温 $27^{\circ} \mathrm{C}$ に放射の影響の温度換算值 $+1.31^{\circ} \mathrm{C}$ 之湿度 - 気流 ・着衣の効果の温度換算値の平均 值を加えるとSET*の值 $25.51^{\circ} \mathrm{C}$ となる。計算結果の一覧 をSET*とぬれ面積率の值とともに表一 1 に示す。また 表 $-2 \sim$ 表 -6 には，放射(放射温 $=$ 入温 $\left.+3^{\circ} \mathrm{C}\right)$ ，気流 $(0.5 \mathrm{~m} / \mathrm{s})$, 着衣量 $(0.4 \mathrm{clo})$ の条件は前述の場合と同一で, 気温と湿度の条件が高温低湿 $\left(27^{\circ} \mathrm{C}, 20 \%\right)$ ，中温高湿(24 $\left.{ }^{\circ} \mathrm{C}, 80 \%\right)$, 中温低湿 $\left(24^{\circ} \mathrm{C}, 20 \%\right)$, 低温高湿 $\left(21^{\circ} \mathrm{C}, 80 \%\right)$, 低温低湿 $\left(21^{\circ} \mathrm{C} ， 20 \%\right)$ であるような環境での標準化の順 番が異なる場合の温度換算値の一覧を示す。表一 1 に示 した高温高湿条件に比べる，低温側または低湿側の条 件ではぬれ面積率が小さく湿度の影響が少なくなり，標 準化の順番の相違による温度換算値のばらつきは小さく なる傾向にある。

\section{5.まとめ}

単一温度指標であるために個々の温熱要素の影響を個 別に把握することのできないSET*において，SET*を導 出する考方方と同様の方法により，放射・湿度・気流・ 着衣の 4 つの温熱要素の影響を温度換算する方法を示し た。またSET*は，基準となる気温にこれらの温度換算 值を加え合わせたものとして表すことが可能である。た だし，ここで提示した方法では湿度・気流・着衣の各要 素の温度換算値は緟密には独立でなく，各温熱要素の影 響を完全に分離できない憾みがある。しかし，高温・高 湿環境以外では各要素の標準化の順番の相違による温度 換算値の差は小さく，実用的にはそれぞれの温度換算値 を平均した值で温熱要素の効果の把握が十分に可能と考 えられる。また，図ー2や各表に示したような各段階に 


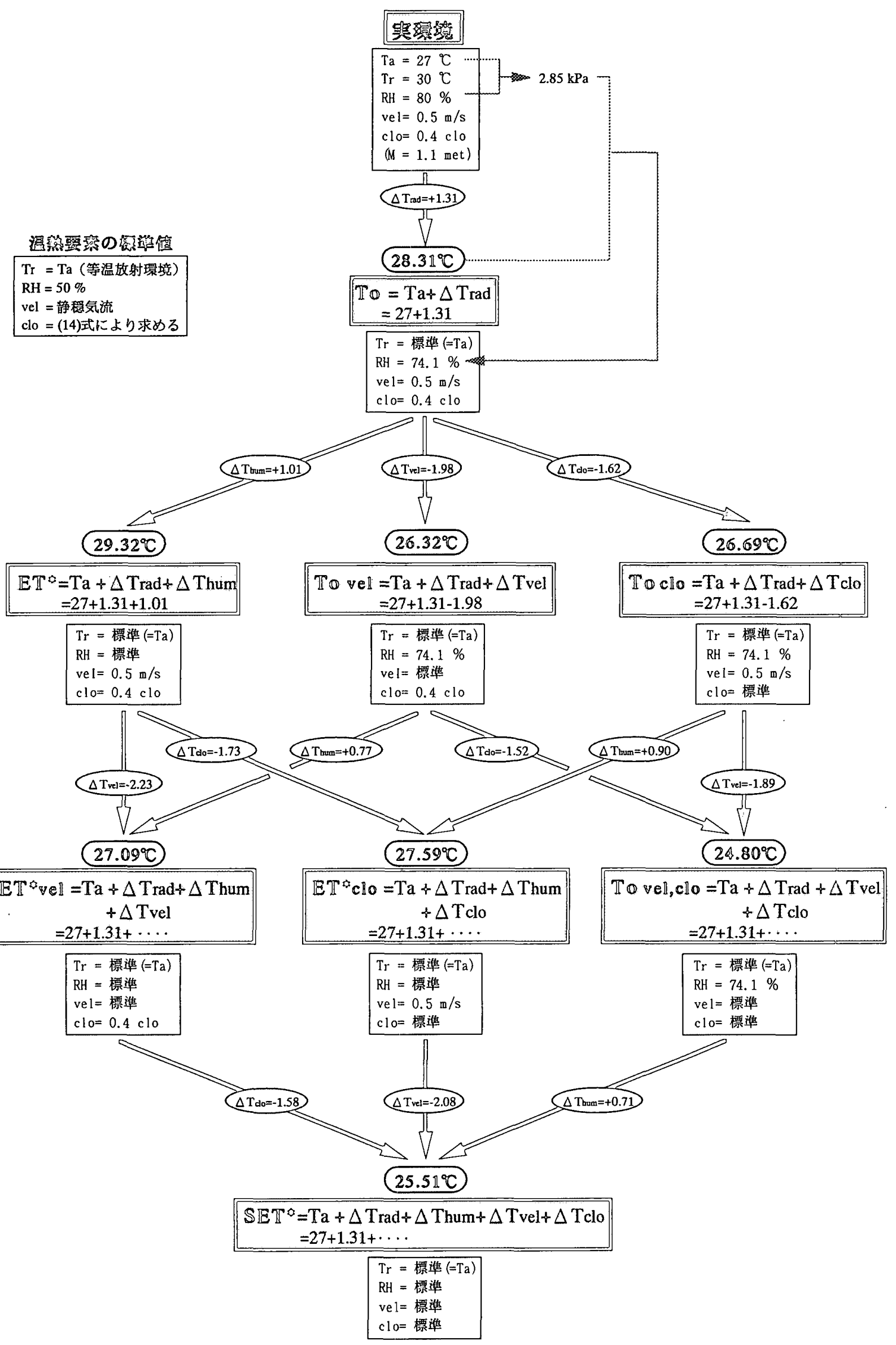

図-2 温熱的等価環境の温度の変化と標準化の順番の相違にともなう各温熱要素の影響の温度換算値 
おける個別の温度換算値を参照すれば，より正確な把握 が可能である。

今後は各要素の効果の温度換算值と温熱生理・心理反 応との対応などの実験的な検証および代謝量が異なる場 合の影響の温度換算について検討する必要があろう。

注 1 ) Gaggeが示した標準作用温度(STO) $)^{9), 11)}$ も着衣量と総合熱 伝達率を標準化（放射熱伝達率を一定とすれば，対流熱 伝達率の標準化すなわち気流を標準化したこととほぼ同 義) した作用温度であるか，STOの標準化における温熱 的等価条件では生理的状態値のひとつであるぬれ面積率 を同一にするといった概念はなく、ここで示したTovel,clo とSTOとは異なる。

表- 1 各温熱要素の影響の温度換算值の一覧 高温高湿条件

$\left(\mathrm{Ta}=27^{\circ} \mathrm{C}, \quad \operatorname{Tr}=30^{\circ} \mathrm{C}, \mathrm{RH}=80 \%, \quad 0.5 \mathrm{~m} / \mathrm{s}, 0.4 \mathrm{clo}, 1.1 \mathrm{met}\right)$

\begin{tabular}{|c|c|c|c|c|c|c|}
\hline$\left({ }^{\circ} \mathrm{C}\right)$ & 1 & 2 & 3 & 4 & 平均 & 標準偏差 \\
\hline 放射の影響 & \multicolumn{4}{|c|}{1.31} & - & - \\
\hline 湿度の影響 & 1.01 & 0.77 & 0.90 & 0.71 & 0.85 & 0.14 \\
\hline 気流の影響 & -1.98 & -2.23 & -1.89 & -2.08 & -2.05 & 0.14 \\
\hline 着衣の影響 & -1.62 & -1.73 & -1.52 & -1.58 & -1.61 & 0.09 \\
\hline
\end{tabular}

表-3 各温熱要素の影響の温度換算値の一覧 中温高湿条件

$\left(\mathrm{Ta}=24^{\circ} \mathrm{C}, \operatorname{Tr}=27^{\circ} \mathrm{C}, \mathrm{RH}=80 \%, 0.5 \mathrm{~m} / \mathrm{s}, 0.4 \mathrm{clo}, 1.1 \mathrm{met}\right)$

\begin{tabular}{|c|c|c|c|c|c|c|}
\hline$\left({ }^{\circ} \mathrm{C}\right)$ & 1 & 2 & 3 & 4 & 平均 & 標準偏差 \\
\hline 放射の影覀 & \multicolumn{4}{|c|}{1.29} & - & - \\
\hline 湿度の影䟭 & 0.40 & 0.29 & 0.34 & 0.27 & 0.32 & 0.06 \\
\hline 気流の影䇢 & -1.93 & -2.04 & -1.84 & -1.91 & -1.93 & 0.08 \\
\hline 着衣の影響 & -1.77 & -1.82 & -1.68 & -1.70 & -1.74 & 0.07 \\
\hline
\end{tabular}

表 -5 各温熱要素の影響の温度換算値の一覧 低温高湿条件

$\left(\mathrm{Ta}=21^{\circ} \mathrm{C}, \operatorname{Tr}=24^{\circ} \mathrm{C}, \mathrm{RH}=80 \%, 0.5 \mathrm{~m} / \mathrm{s}, 0.4 \mathrm{clo}, 1.1 \mathrm{met}\right)$

\begin{tabular}{|c|c|c|c|c|c|c|}
\hline$\left({ }^{\circ} \mathrm{C}\right)$ & 1 & 2 & 3 & 4 & 平均 & 標準偏差 \\
\hline 放射の影嘼 & \multicolumn{4}{|c|}{1.27} & - & - \\
\hline 湿度の影知 & 0.33 & 0.24 & 0.29 & 0.22 & 0.27 & 0.05 \\
\hline 気流の影響 & -2.18 & -2.27 & -2.09 & -2.16 & -2.17 & 0.08 \\
\hline 着衣の影響 & 1.89 & -1.93 & -1.80 & -1.82 & -1.86 & 0.06 \\
\hline
\end{tabular}

$\left(\mathrm{SET}^{*}=18.51^{\circ} \mathrm{C} ＼mathrm{~ ぬ 隹 面 稍 率 ~: ~} \mathrm{w}=0.060\right)$

\section{参考文献}

1)Gagge,A.P., Stolwijk,J.A.J., Nishi,Y. : An Effective Temperature Scale Based on a Simple Model of Human Physiological Regulatory Response, ASHRAE Transactions, Vol.77,Part I, pp.247 262,1971

2)Gagge,A.P., Nishi,Y., Gonzalez,R.R. : Standard Effective Temperature - A Single Temperature Index of Temperature Sensation and Thermal Discomfort,Proc. of The CIB Commission W 45 (Human Requirements) Symposium, Thermal Comfort and Moderate Heat Stress, Building Research Station, London September 1972, published by HMSO, pp.229 250, 1973

3)Gagge,A.P., Fobelets, A.P., Berglund,LG.: A Standard Predictive Index of Human Response to the Thermal Environment, ASHRAE Transactions, Vol.92, Part 2B, pp. $709 \sim 731,1986$

4)樑井一夫 - 後藤滋 ·斎藤純司 - 伊藤宏 : 標準新有効温度 $\left(\mathrm{SET}^{*}\right)$ と日本人の温熱感党に関する実験的研究（第 1 報） 冬季被験者実験による検討, 空気調和・衛生工学会論文 集, No.48, pp.21 29，1992

表-2 各温熱要素の影響の温度換算值の一覧 高温低湿条件

$\left(\mathrm{Ta}=27^{\circ} \mathrm{C}, \mathrm{Tr}=30^{\circ} \mathrm{C}, \mathrm{RH}=20 \%, 0.5 \mathrm{~m} / \mathrm{s}, 0.4 \mathrm{clo}, 1.1 \mathrm{met}\right)$

\begin{tabular}{|c|c|c|c|c|c|c|}
\hline$\left({ }^{\circ} \mathrm{C}\right)$ & 1 & 2 & 3 & 4 & 平均 & 摽浲偏差 \\
\hline 放射の影噿 & \multicolumn{4}{|c|}{1.30} & - & - \\
\hline 湿度の影悔 & -0.75 & -0.55 & -0.66 & -0.51 & -0.62 & 0.11 \\
\hline 気流の影䂹 & -2.18 & -1.98 & -2.01 & -1.86 & -2.01 & 0.13 \\
\hline 着衣の影嗨 & -1.81 & -1.73 & -1.64 & -1.60 & -1.70 & 0.09 \\
\hline
\end{tabular}

表 - 4 各温熱要素の影響の温度換算值の一覧 中温低湿条件

$\left(\mathrm{Ta}=24^{\circ} \mathrm{C}, \operatorname{Tr}=27^{\circ} \mathrm{C}, \mathrm{RH}=20 \%, 0.5 \mathrm{~m} / \mathrm{s}, 0.4 \mathrm{clo}, 1.1 \mathrm{met}\right)$

\begin{tabular}{|c|c|c|c|c|c|c|}
\hline$\left({ }^{\circ} \mathrm{C}\right)$ & 1 & 2 & 3 & 4 & 平均 & 標染偏差 \\
\hline 放射の影曏 & \multicolumn{4}{|c|}{1.29} & - & - \\
\hline 湿度の影盽 & -0.50 & -0.38 & -0.44 & -0.34 & -0.42 & 0.07 \\
\hline 気流の影嘼 & -2.17 & -2.04 & -2.03 & -1.93 & -2.04 & 0.10 \\
\hline 着衣の影栯 & -1.90 & -1.84 & -1.76 & -1.72 & -1.80 & 0.08 \\
\hline
\end{tabular}

表一 6 各温熱要素の影響の温度換算值の一覧 低温低湿条件

$\left(\mathrm{Ta}=21^{\circ} \mathrm{C}, \operatorname{Tr}=24^{\circ} \mathrm{C}, \mathrm{RH}=20 \%, 0.5 \mathrm{~m} / \mathrm{s}, 0.4 \mathrm{clo}, 1.1 \mathrm{met}\right)$

\begin{tabular}{|c|c|c|c|c|c|c|}
\hline$\left({ }^{\circ} \mathrm{C}\right)$ & 1 & 2 & 3 & 4 & 平均 & 標染偏差 \\
\hline 放射の影響 & \multicolumn{4}{|c|}{1.27} & - & - \\
\hline 湿度の影要 & -0.43 & -0.31 & -0.38 & -0.28 & -0.35 & 0.07 \\
\hline 気流の影嵒 & -2.47 & -2.36 & -2.35 & -2.25 & -2.36 & 0.09 \\
\hline 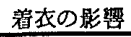 & 1.88 & -1.83 & -1.75 & -1.72 & -1.80 & 0.07 \\
\hline
\end{tabular}

$\left(\mathrm{SET}^{*}=17.76^{\circ} \mathrm{C}, ぬ\right.$ 面糟率 : $\left.\mathrm{w}=0.060\right)$

温度換算值一覧表の各数值の説明（表 $-1 \sim 6$ に共通）

\begin{tabular}{|c|c|c|c|c|}
\hline & 1 & 2 & 3 & 4 \\
\hline 放射の堐唩 & \multicolumn{4}{|c|}{$\mathrm{To}-\mathrm{Ta}$} \\
\hline 湿度の影筧 & $\mathrm{ET}^{*}-\mathrm{To}$ & ET"vel-Tovel & ET"clo-Toclo & SET* $^{*}$ Tovel,clo \\
\hline 気流の曟掏 & Tovel-To & $\mathrm{ET}^{*}{ }^{*} \mathrm{vel}-\mathrm{ET}^{*}$ & Tovel,clo-Toclo & $\mathrm{SET}^{*}-\mathrm{ET}^{*} \mathrm{clo}$ \\
\hline 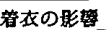 & Toclo-To & $\mathrm{ET}^{*} \mathrm{clo}^{-\mathrm{ET}^{*}}$ & Tovel,cla-Tovel & SET*-ET"vel \\
\hline
\end{tabular}


5)深井一夫・後藤滋・斎藤純司・伊藤宏・阿久井哲：標準 新有効温度 $\left(\mathrm{SET}^{*}\right)$ と日本人の温熱感覚に関する実験的研 究 (第 2 報) 冬季および夏季における温熱感覚の比較, 空気調和・衛生工学会論文集 No.51, pp.139 147, 1993

6)深井一夫・斎藤純司・伊藤宏・後藤滋 : 代謝量の異なる 場合の標準新有効温度 $\left(\mathrm{SET}^{*}\right)$ 之温熱感覚の関係 歩行時 と椅座安静時の比較, 空気調和・衛生工学会論文集, No.55, pp.99 109，1994

7)滐井一夫・伊藤宏ほか：SET" と温熱感覚の関係について （その 7 ）着衣の異なる場合のSET 之温冷感の相関，空 気調和・衛生工学会学術講演会講演論文集, pp.565 568,1992

8)伊藤宏・澡井一夫ほか：SET ${ }^{*}$ と温熱感覚の関係について （その 8) 着衣の異なる場合の温冷感・不快感・満足感 の検討, 空気調和・衛生工学会学術講演会講演諭文集, pp.569 572, 1992
9)堀越哲美・小林陽太郎：総合的な温熱環境指標としての 修正湿り作用温度の研究，日本建築学会計画軽論文報告 集 第335号, pp.12 19，1985

10)堀越哲美・小林陽太郎・土川忠浩・福島重治 : 修正湿り 作用温度・温熱風速場・有効放射場および減効湿度場に よる温熱環境条件の人体影響表現方法の検討，日本建築 学会計画軽論文報告集 第380号, pp.12 23，1987

11)西安信 : 温熱評価之熱平衡, 温熱生理学 (中山昭雄編)， pp.61 63, 理工学社, 1981

12)Gagge,A.P., Rapp, G.M., Hardy, J.D. : The Effective Radiant Field and Operative Temperature Necessary for Comfort with Radiant Heating, ASHRAE Transactions, Vol.73, Part I, pp.I.2.1-I.2.9, 1967

（1994 年 3 月 8 日原稿受理，1994 年 9 月 19 日採用決定） 